\title{
Geochemistry of coexisting hornblende and biotite from the Ambalavayal granite, Kerala
}

\author{
M SANTOSH \\ Centre for Earth Science Studies, P.B. 2235, Sasthamangalam, Trivandrum 695010, India \\ MS received 1 February 1985; revised 19 December 1985 \begin{abstract}
from the Ambalavayal granite, northern Kerala, are presented. The hornblendes correspond to edenitic composition, whereas the biotites coirespond to annite. The hornblendes typically show high $\mathrm{Al}_{2} \mathrm{O}_{3}$ contents $(9.69-11.89 \%)$ comparable with those from anorogenic granites. The biotites are characteristically low Mg-type, similar to those reported from alkaline rocks. The distribution coefficients calculated for all the major and trace elements are presented and an evaluation of the nature of variation indicate near-chemical equilibrium conditions during the crystallization of the two minerals. The hornblende-biotite tie lines in the $\mathrm{Fe}^{3+}-\mathrm{Fe}^{2+}-\mathrm{Mg}$ compositional triangle, lie parallel to those of buffered biotites, indicating crystallization in an environment closed to oxygen and well above the Ni-NiO buffer. It is inferred that the $\mathrm{fH}_{2} \mathrm{O}$ increased towards the residual stage and $\mathrm{fO}_{2}$ values were high, in the range of $10^{-15}$ bars.
\end{abstract} \\ Abstract. Major and trace element geochemistry of coexisting hornblendes and biotites
}

Keywords. Granite; hornblende; biotite; geochemistry; distribution coefficients; $\mathrm{TH}_{2} \mathrm{O} ; \mathrm{fO}_{2}$; Ambalavayal.

\section{Introduction}

The 595 million year (m.y.) old granite pluton of Ambalavayal in Wynad district of northern Kerala, emplaced within Precambrian biotite gneisses, is a typical member of the Late Precambrian Early Paleozoic granitic intrusives in the south-western Indian shield (Nair et al 1982; Santosh et al 1985). The granite is spatially related to the Moyar fault zone and the associated pegmatites and quartz veins show disseminated molybdenite mineralization, marking an event of taphrogenic metallogeny (Santosh and Nair 1983). Geochemical characters denote an alkaline nature and tectonic aspects suggest a probable anorogenic affiliation, like the other plutons in the region. This paper presents the major and trace element geochemistry of hornblende and biotite, the principal mafic minerals in the granite, based on which the conditions of crystallization are deciphered.

The granite is pink, medium grained and composed of interlocking quartz and alkali feldspar. Plagioclase of albitic composition occurs in subordinate amounts. The hornblende (constituting 3.74-5.63 volume \%) and biotite (3.88-5.23 volume \%) occur as subhedral laths with textural relations generally suggesting their formation towards the later stages of crystallization history as they commonly form interstitial laths between grains of plagioclase and perthite. Biotite shows a pleochroic scheme of $X<Y$ $=Z$, where $X=$ straw yellow and $Y=Z=$ dark greyish brown, whereas the pleochroism of hornblende is $X<Y \leqslant Z$ with $X=$ yellowish green, $Y=$ green and $Z$ $=$ deep bluish green. The accessories include zircon, apatite, epidote, monazite and sphene. Minor reibeckite is also noted, showing deep blue colour, anomalous extinction and $Z \Lambda c$ varying between $3-9^{\circ}$. The opaque is mainly magnetite. 
Hornblende and biotite fractions for the present study were obtained by mineral separation involving a combination of repeated heavy liquid and electromagnetic techniques. The final purity of the samples were checked by hand picking under a stereo-microscope and was found to be about $99 \%$.

The major elements were analysed by conventional wet chemical techniques and trace elements by atomic absorption spectrophotometer (Perkin-Elmer-4000), calibrated using internal standards.

\section{Geochemistry of biotite}

The chemical analyses of biotite samples from Ambalavayal and their structural formulae (based on 22 atoms, anhydrous) are presented in table 1 . Si cations range from 5.570 to 5.923 per formula unit compared to 6.000 for ideal phlogopite-annite series.

Table 1. Chemical analyses and structural formulae of biotite from Ambalavayal.

\begin{tabular}{|c|c|c|c|c|c|c|}
\hline & $\mathrm{A} / \mathrm{BT} / 1$ & $\mathrm{~A} / \mathrm{BT} / 2$ & $\mathrm{~A} / \mathrm{BT} / 3$ & $\mathrm{~A} / \mathrm{BT} / 4$ & $\mathrm{~A} / \mathrm{BT} / 5$ & $\mathrm{~A} / \mathrm{BT} / \mathrm{6}$ \\
\hline \multicolumn{7}{|l|}{ Chemical analyses } \\
\hline $\mathrm{SiO}_{2}$ & 35.01 & $36 \cdot 10$ & $36 \cdot 28$ & $37 \cdot 10$ & 38.18 & 37.51 \\
\hline $\mathrm{Al}_{2} \mathrm{O}_{3}$ & $13 \cdot 77$ & $13 \cdot 26$ & 14.62 & 12.75 & 14.07 & 12.82 \\
\hline $\mathrm{TiO}_{2}$ & 2.80 & 2.88 & $2 \cdot 23$ & $2 \cdot 60$ & 1.96 & $2 \cdot 14$ \\
\hline $\mathrm{Fe}_{2} \mathrm{O}_{3}$ & 5.02 & $5 \cdot 44$ & 5.21 & 8.39 & 7.46 & 6.47 \\
\hline $\mathrm{FeO}$ & $29 \cdot 21$ & $28 \cdot 10$ & 26.28 & 26.05 & $21 \cdot 37$ & 25.86 \\
\hline $\mathrm{MnO}$ & 0.33 & 0.42 & 0.46 & 018 & 0.53 & 0.34 \\
\hline $\mathrm{MgO}$ & 0.96 & $1 \cdot 12$ & 1.42 & 0.65 & 2.02 & 0.84 \\
\hline $\mathrm{CaO}$ & 1.57 & 1.84 & $1 \cdot 13$ & $1 \cdot 12$ & 1.48 & $1 \cdot 12$ \\
\hline $\mathrm{Na}_{2} \mathrm{O}$ & 0.80 & 0.76 & 0.74 & 0.65 & 0.58 & 0.63 \\
\hline $\mathrm{K}_{2} \mathrm{O}$ & 8.51 & 7.89 & $9 \cdot 12$ & $8 \cdot 10$ & 8.98 & 8.42 \\
\hline $\mathrm{P}_{2} \mathrm{O}_{5}$ & 0.43 & 0.52 & 0.59 & 0.57 & 0.54 & 0.58 \\
\hline Moisture & 0.44 & 0.66 & 0.25 & 0.18 & 0.28 & 0.18 \\
\hline LOI & 0.81 & 0.98 & 0.73 & 1.68 & 0.56 & $1 \cdot 64$ \\
\hline Total & 99.66 & 99.97 & 99.06 & 100.02 & 98.01 & 98.55 \\
\hline \multicolumn{7}{|c|}{ Structural formulae* } \\
\hline $\mathrm{Si}$ & 5.570 & 5.697 & 5.732 & 5.830 & 5.923 & 5.955 \\
\hline $\mathrm{Al}^{\mathrm{jiv}}$ & $2 \cdot 430$ & $2 \cdot 303$ & $2 \cdot 268$ & $2 \cdot 170$ & 2.077 & 2.045 \\
\hline Alvi & 0.153 & 0.164 & 0.455 & $0-192$ & $0-496$ & 0.356 \\
\hline $\mathrm{Ti}$ & $0-336$ & 0.343 & $0-265$ & 0.307 & 0.229 & 0.256 \\
\hline $\mathrm{Fe}^{3+}$ & 0.601 & 0.647 & $0-619$ & 0.991 & 0.871 & 0.773 \\
\hline $\mathrm{Fe}^{2+}$ & 3.886 & 3.709 & 3.472 & 3.423 & 2.772 & 3.434 \\
\hline $\mathrm{Mn}$ & 0.045 & 0.056 & 0.062 & 0.024 & 0.070 & 0.046 \\
\hline $\mathrm{Mg}$ & 0.228 & $0-264$ & 0.334 & 0.150 & 0.467 & 0.198 \\
\hline $\mathrm{Ca}$ & 0.268 & 0.311 & $0-191$ & 0.189 & 0.246 & 0.191 \\
\hline $\mathrm{Na}$ & 0.246 & 0.234 & 0.036 & $0-198$ & 0.176 & 0.194 \\
\hline K & 1.726 & 1.592 & $0-919$ & $1 \cdot 624$ & 1.776 & 1.706 \\
\hline Sum $Y$ & 5.249 & $5 \cdot 183$ & $5 \cdot 207$ & 5.087 & 4.905 & 5.063 \\
\hline $\operatorname{Sum} X$ & $2 \cdot 240$ & $2: 137$ & 2.065 & $2 \cdot 011$ & $2 \cdot 198$ & 2091 \\
\hline $\mathrm{Mg} / \mathrm{Mg}+\mathrm{Fe}^{2+}$ & 0.055 & 0.067 & 0.088 & 0.042 & 0.209 & 0.055 \\
\hline
\end{tabular}

*Based on 22 oxygens per formula unit; Lol-loss on ignition. 
There is sufficient $\mathrm{Al}$ in the sample to fill the tetrahedral sites not occupied by Si. The octahedral sites are occupied by 4.905 to $5.249 \mathrm{Y}$ group cations compared with 6.000 in the trioctahedral mica. The sum of the inter-layer $X$ group cations $(\mathrm{K}, \mathrm{Na}, \mathrm{Ca})$ ranges from 2.011 to 2.240 , compared with the ideal 2.000 cations per formula unit. Plots of $\mathrm{Fe} / \mathrm{Fe}+\mathrm{Mg}$ ratios of biotite against $\mathrm{Al}$ atoms/22 oxygens define a field close to the annite-phlogopite join (figure 1), with Al atoms indicating composition close to that of annite $(2 \cdot 2-2 \cdot 8)$.

The most striking feature of the biotites is the very low magnesium content of the octahedral layers $(0 \cdot 150-0 \cdot 467)$. Figure 2 depicts a comparison of the composition of these biotites with those delineated for biotites from elsewhere. The Ambalavayal biotites lie outside Foster's (1960) field, away from the $\mathrm{Mg}$ apex and are comparable

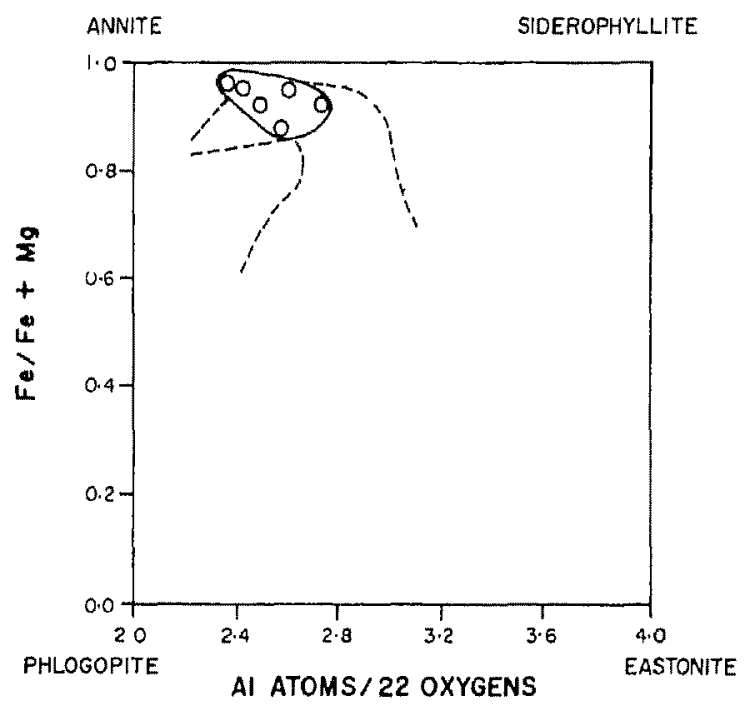

Figure 1. Composition of Ambalavayal biotite in terms of $\mathrm{Fe} / \mathrm{Fe}+\mathrm{Mg}$ vs $\mathrm{Al}$ atoms/22 oxygens. The broken lines represent the field of biotites as given by Anderson (1980).

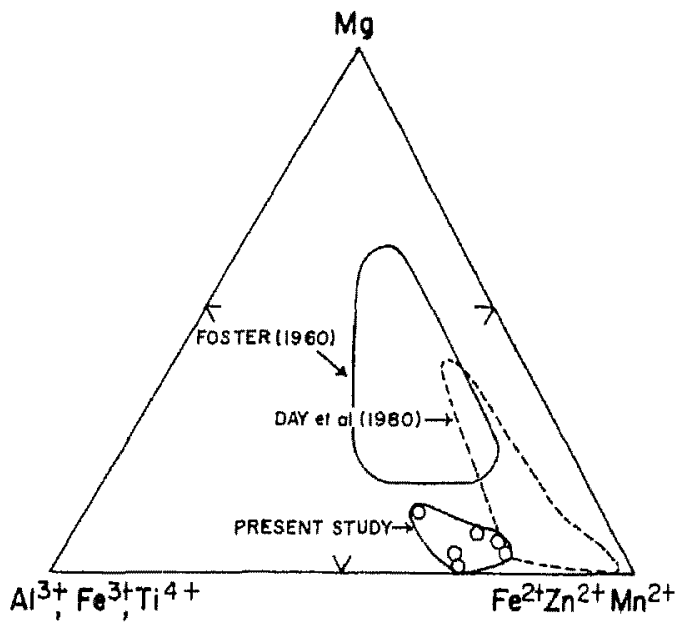

Figure 2. Composition of Ambalavayal biotites compared with those from elsewhere (note the low $\mathrm{Mg}$-content) 
with low $\mathrm{Mg}$ biotites from alkaline environments reported by Day et al (1980). The biotites show low sodium content in the alkali site varying from 0.036 to 0.246 . These characters are comparable with those for biotites from alkaline rocks (cf. Czamanske $e t$ al 1977).

\section{Geochemistry of hornblende}

Chemical analyses and structural formulae (based on 23 oxygen atoms, anhydrous) of hornblende separates from Ambalavayal granite are presented in table 2 . The analyses and structural formulae overall satisfy the requirements for 'superior analyses' and indicate an edenitic composition (Leake 1978). Si cations range from 6.306 to 6.920 per formula unit with sufficient Al in all the samples to fill the tetrahedral sites not occupied

Table 2. Chemical analyses and structural formulae of hornblende from Ambalavayal.

\begin{tabular}{|c|c|c|c|c|c|c|}
\hline & $\mathrm{A} / \mathrm{HB} / 1$ & $\mathrm{~A} / \mathrm{HB} / 2$ & $\mathrm{~A} / \mathrm{HB} / 3$ & $\mathrm{~A} / \mathrm{HB} / 4$ & $\mathrm{~A} / \mathrm{HB} / 5$ & $\mathrm{~A} / \mathrm{HB} / 6$ \\
\hline \multicolumn{7}{|c|}{ Chenical analyses } \\
\hline $\mathrm{SiO}_{2}$ & 39.83 & 40.23 & $39 \cdot 45$ & 39.83 & $41 \cdot 21$ & 39.78 \\
\hline $\mathrm{Al}_{2} \mathrm{O}_{3}$ & $10 \cdot 20$ & 10.67 & 11.89 & 10.71 & 10.71 & $9 \cdot 69$ \\
\hline $\mathrm{TiO}_{2}$ & 1.42 & $1 \cdot 41$ & 1.35 & 1.53 & 1.58 & 1.53 \\
\hline $\mathrm{FeO}_{3}$ & 5.58 & $5 \cdot 11$ & 4.96 & 6.80 & 6.56 & 6.68 \\
\hline $\mathrm{FeO}$ & $20 \cdot 20$ & $20-42$ & 20.61 & 22.85 & 19.80 & $23 \cdot 40$ \\
\hline $\mathrm{MnO}$ & 0.53 & 0.64 & 0.61 & 0.55 & 0.42 & 0.56 \\
\hline $\mathrm{MgO}$ & 2.72 & 4.01 & 3.86 & 2.56 & $2 \cdot 56$ & 2.56 \\
\hline $\mathrm{CaO}$ & 1053 & 9.22 & 8.78 & 9.41 & 7.51 & 10.30 \\
\hline $\mathrm{Na}_{2} \mathrm{O}$ & 1.87 & 1.79 & 1.94 & $2 \cdot 15$ & $2 \cdot 01$ & 213 \\
\hline $\mathrm{K}_{2} \mathrm{O}$ & 2.41 & 1.98 & $2 \cdot 21$ & 1.78 & $2 \cdot 48$ & 1.78 \\
\hline $\mathrm{P}_{2} \mathrm{O}_{5}$ & 0.31 & 0.28 & 0.12 & 0.22 & 0.16 & 0.15 \\
\hline Moisture & 2.21 & 1.02 & 1.97 & 1.08 & 1.85 & 1.97 \\
\hline LOI & 1.95 & 1.95 & $2 \cdot 22$ & 0.97 & 2.56 & 2.65 \\
\hline Total & 99.76 & 98.53 & 99.97 & $100 \cdot 44$ & $99-41$ & $98 \cdot 41$ \\
\hline \multicolumn{7}{|c|}{ Strustural formulae* } \\
\hline $\mathrm{Si}$ & 6.947 & 6.443 & 6.337 & 6.306 & 6.716 & $6 \cdot 371$ \\
\hline$A I^{j p}$ & $1 \cdot 053$ & 1.557 & 1.663 & 1.694 & 1.784 & 1.629 \\
\hline$A]^{v i}$ & $0-894$ & 0.442 & 0.526 & 0.306 & 0.774 & 0.154 \\
\hline $\mathrm{Ti}$ & 0.175 & 0.170 & $0-163$ & 0.182 & 0.191 & 0.135 \\
\hline $\mathrm{Fe}^{3+}$ & 0.673 & 0.616 & 0.601 & 0.811 & 0.805 & 0.809 \\
\hline $\mathrm{Fe}^{2+}$ & 2.734 & 2.735 & 2.769 & 3.025 & 2.700 & $3 \cdot 137$ \\
\hline $\mathrm{Mn}$ & 0073 & 0.086 & 0.083 & 0.074 & 0.058 & 0.077 \\
\hline $\mathrm{Mg}$ & 0.656 & 0.957 & 0.924 & 0.604 & 0.622 & 0.606 \\
\hline $\mathrm{Ca}$ & 1.826 & 1.582 & 1.512 & 1.596 & 1322 & 1.771 \\
\hline $\mathrm{K}$ & 0.588 & 0.556 & 0.604 & 0.660 & 0.634 & 0.654 \\
\hline $\mathrm{Na}$ & 0.498 & 0.404 & 0.454 & 0.360 & 0.514 & 0.366 \\
\hline Sum Y & 5.205 & 5.019 & 5.066 & 5.002 & $5 \cdot 150$ & 4.918 \\
\hline Sum $W+X$ & 2.912 & 2.542 & 2.570 & 2.616 & $2 \cdot 472$ & 2.791 \\
\hline $\mathrm{Mg} / \mathrm{Mg}+\mathrm{Fe}^{2+}$ & 0194 & 0.259 & 0.250 & 0.166 & 0.187 & 0.162 \\
\hline
\end{tabular}

*Based on 23 oxygens per formula unit; LOI-loss on ignition 
by Si. The total number of $Y$ group cations range from 4.891 to $5 \cdot 205$ per formula unit compared with 5.0 in the ideal hornblende formula.

A notable aspect is the high Al-content of the hornblende $\left(\mathrm{Al}_{2} \mathrm{O}_{3}=9.69-11.89 \%\right)$, which compares with the characteristic high $\mathrm{Al}_{2} \mathrm{O}_{3}$ values of hornblendes from anorogenic granites $(9-11$ weight \%) and contrast with the low Al values for hornblendes from calc-alkaline plutons associated with orogenic belts (Anderson 1980). In all samples except one, the sum of $W$ and $X$ group cations (Ca, Na, K) exceed the theoretical maximum of 2.000 cations per formula unit in the $M_{4}$ site and suggests partial occupation of the $A$ sites. The $\mathrm{Mg} / \mathrm{Mg}+\mathrm{Fe}^{2+}$ values are fairly uniform, ranging between $0 \cdot 162$ and $0 \cdot 259$.

\section{Distribution of major elements}

For coexisting minerals $\alpha$ and $\beta$, the distribution coefficient of element $A$ is defined as:

$$
K_{D(A)}^{\alpha-\beta}=\frac{X_{A}^{\alpha}}{1-X_{A}^{\alpha}} \frac{1-X_{A}^{\beta}}{X_{A}^{\beta}}
$$

where $X_{A}$ is the atomic ratio of element $A$ to the sum of major elements occupying the same site or sites in phases $\alpha$ and $\beta$. If the elements considered behave as ideal mixtures and reach chemical equilibrium under uniform $P-T$ conditions, then the distribution coefficient, $K_{D(A)}$ is constant ( $c f . \mathrm{Kretz} 1959,1960$; Stephenson 1977). The distribution coefficient, $K_{D\left(\mathrm{Fe}^{2+}\right.}^{B-\mathrm{Mg})}$ was calculated using the atomic ratio, $\mathrm{Fe}^{2+} /\left(\mathrm{Fe}^{2+}+\mathrm{Mg}\right)$. $K_{D(A)}^{B-A}$ was calculated using the atomic ratio, $A \mathrm{~A}^{\mathrm{iv}} /\left(\mathrm{A} \mathrm{I}^{\mathrm{iv}}+\mathrm{Si}\right)$. For the remaining distribution coefficients, the atomic ratio of the element considered is based on the total number of octahedral cations, e.g., for $K_{D(C a)}^{B-H}, X_{C_{a}}=\mathrm{Ca} / \Sigma$ octahedral cations. The calculated atomic ratios of elements to the sum of major elements occupying the

Table 3. Atomic ratio of elements to the sum of major elements occupying the respective sites in hornblende and biotite from Ambalavayal.

\begin{tabular}{|c|c|c|c|c|c|c|c|c|}
\hline & $X_{\mathrm{A} i v}^{H}$ & $X_{A{ }^{v i}}^{H}$ & $X_{\mathrm{T} i}^{H}$ & $x_{\mathrm{F}^{3 *}}^{H}$ & $X_{\mathrm{Fe}^{3+}}^{H}$ & $X_{\mathrm{Mn}}^{H}$ & $X_{M_{\mathrm{B}}}^{H}$ & $X_{C a}^{H}$ \\
\hline \multicolumn{9}{|c|}{ Homblende } \\
\hline $\mathrm{A} / \mathrm{HB} / 1$ & 0.132 & 0.172 & 0.034 & 0.129 & 0.525 & 0.014 & 0.126 & 0,670 \\
\hline $\mathrm{A} / \mathrm{HB} / 2$ & 0.195 & 0.088 & 0.034 & 0.123 & 0.545 & 0.017 & 0.191 & 0.622 \\
\hline $\mathrm{A} / \mathrm{HB} / 3$ & 0.209 & $0-104$ & 0.032 & 0.119 & 0.547 & 0.017 & 0.182 & 0.588 \\
\hline $\mathrm{A} / \mathrm{HB} / 4$ & 0.212 & 0.061 & 0.036 & 0.162 & 0.605 & 0.015 & $0-121$ & 0.610 \\
\hline $\mathrm{A} / \mathrm{HB} / 5$ & 0.223 & 0.150 & 0.037 & 0.156 & 0.524 & 0.011 & 0.121 & 0.535 \\
\hline \multirow[t]{2}{*}{$\mathrm{A} / \mathrm{HB} / 6$} & $0-204$ & 0.031 & 0.028 & $0-165$ & 0.638 & $0-016$ & 0.123 & 0635 \\
\hline & $X_{A^{j w}}^{B}$ & $X_{A^{v i}}^{B}$ & $X_{f_{i}}^{p_{1}}$ & $x_{\mathrm{F}^{3+}}^{\mathrm{3}+}$ & $X_{\mathrm{Fe}^{2+}}^{\beta}$ & $X_{M n}^{\beta}$ & $X_{\mathrm{Mg}}^{B}$ & 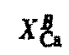 \\
\hline \multicolumn{9}{|l|}{ Biotite } \\
\hline $\mathbf{A} / \mathbf{B T} / 1$ & 0.304 & 0.029 & 0.114 & 0115 & 0.740 & 0.009 & 0.043 & 0.120 \\
\hline $\mathrm{A} / \mathbf{B T} / 2$ & $0-288$ & 0.032 & 0.066 & 0.125 & 0.716 & 0.011 & 0.051 & 0.146 \\
\hline $\mathbf{A} / \mathbf{B T} / \mathbf{3}$ & $0-284$ & 0.087 & 0.051 & 0.119 & 0.667 & 0.012 & 0.064 & 0.093 \\
\hline $\mathrm{A} / \mathrm{BT} / 4$ & 0.271 & 0.038 & 0.060 & 0195 & 0.673 & 0.005 & 0.030 & 0.094 \\
\hline $\mathrm{A} / \mathrm{BT} / 5$ & 0.260 & 0.101 & 0.047 & 0.178 & 0.565 & 0.014 & 0.095 & 0.112 \\
\hline $\mathrm{A} / \mathrm{BT} / 6$ & .0 .256 & 0.070 & 0.051 & 0.153 & 0.524 & 0,009 & 0.039 & 0.091 \\
\hline
\end{tabular}


respective sites in coexisting hornblendes and biotites from Ambalavayal are given in table 3 and the distribution coefficients are given in table 4 . The variations in $K_{p}$ values of each element are shown in figure 3 , where the linear to curvilinear trends depict nearchemical equilibrium conditions of crystallization of the two minerals.

Among the tetrahedrally coordinated cations, $\mathrm{Al}$ and $\mathrm{Si}$ show variable distribution with $K_{D\left(\left.A\right|^{N}\right)}^{B-h}$ ranging from 1.255 to 2.303. The distribution of $A 1^{i v}$ and $\mathrm{Si}$ between coexisting homblende and biotite is shown to be non-ideal with their $K_{D}$ values systematically related to the $A l^{\text {iv }}$ contents of hornblende (Gorbatschev 1970). The linear distribution pattern of $X_{A^{i v}}^{H}$ and the curvilinear trend of $X_{A^{n}}^{B}$ and $K_{D\left(A \|^{(N)}\right.}^{B-H}$ depicts that the Al-Si distribution coefficient is related to compositional variables (Stephenson 1977). A check on the trend defined by $\mathrm{Al}^{\mathrm{iv}}$ and Si between the coexisting minerals as per the equation of Gorbatschev (1970) indicate near-chemical equilibrium conditions.

Among the octahedral cations (table 4), $K_{D\left(r_{e}^{2+}\right)}^{B-H}$ ranges from 1.063 to 1.410 and $K_{D\left(\mathrm{M}_{\mathrm{g}}\right)}^{B H}$ ranges from 0.248 to $0.785 . K_{D\left(\mathrm{Fe}^{2+}\right.}^{\left.B-\mathrm{M}_{8}\right)}$ elationship was also checked and found to be uniform, consistent with the observations of other workers (cf. Saxena 1966; Leelanandam 1970). The variation trends of $\mathrm{Al}^{v i}$ in biotite and $\mathrm{Al}^{\mathrm{vi}}, \mathrm{Fe}^{3+}, \mathrm{Ca}, \mathrm{Mn}$ and $\mathrm{Ti}$ in hornblende are rather ambiguous and the trend lines drawn are only overall estimates.

The higher charged octahedral cations like $\mathrm{Fe}^{3+}, \mathrm{Al}^{\mathrm{vi}}$ and Ti show overall uniform distribution. The increase in $K_{b(\mathrm{M})}^{B-H}$ values against increasing $\mathrm{Mn}$ content in biotite (figure 4a) and their negative correlation in hornblende are consistent with similar observations of Saxena (1966) and Kretz (1959). The non-ideal distribution of Ti and $A{ }^{i j}$ between hornblende and biotite also correlates with their observations with the feature attributed to be a result of variation in $\mathrm{Al}^{\mathrm{iv}}, \mathrm{Al}^{\mathrm{vi}}, \mathrm{Fe}^{3+}$ and alkalies in hornblende ( $\mathrm{Kretz}$ 1960). $\mathrm{Fe}^{2+}$ and $\mathrm{Ca}$ in biotite show good fit against their respective $K_{D}$ values, whereas in hornblende, the Ca distribution is not strictly regular.

\section{Distribution of trace elements}

The trace element geochemistry of hornblendes and biotites from Ambalavayal is presented in table 5 and the distribution coefficients are given in table 6 . The pattern of distribution of elements between the coexisting minerals are shown in figure 4 , where the $K_{D}$ values are plotted against the respective $K_{D\left(\mathrm{Mg}-\mathrm{F}_{\mathrm{E}}\right)}^{B-H}$ value. Systematic relationship Table 4. Distribution coefficients for coexisting homblende and biotites from
Ambalavayal.

\begin{tabular}{ccccccccc}
$K^{8-H}$ & $D\left(\mathrm{Al}^{\mathrm{i}}\right)$ & $D(\mathrm{Alvi})$ & $D\left(\mathrm{Fe}^{3+}\right)$ & $D\left(\mathrm{Fe}^{2+}\right)$ & $D(\mathrm{Ti})$ & $D(\mathrm{Mn})$ & $D(\mathrm{Mg})$ & $D(\mathrm{Ca})$ \\
\hline 1 & 2.303 & 0.169 & 0.891 & 1.410 & 3.353 & 1.614 & 0.341 & 0.179 \\
2 & 1.477 & 0.364 & 1.016 & 1.314 & 1.941 & 0.647 & 0.267 & 0.235 \\
3 & 1.359 & 0.837 & 1.000 & 1.219 & 1.594 & 0.727 & 0.352 & 0.158 \\
4 & 1.278 & 0.623 & 1.203 & 1.112 & 1.607 & 0.313 & 0.248 & 0.154 \\
5 & 1.666 & 0.673 & 1.141 & 1.078 & 1.270 & 1.273 & 0.785 & 0.209 \\
6 & 1.255 & 2.258 & 0.927 & 1.063 & 1.821 & 0.130 & 0.317 & 0.143 \\
Mean & 1.468 & 0.821 & 1.030 & 1.199 & 1.931 & 0.784 & 0.385 & 0.180 \\
\hline
\end{tabular}



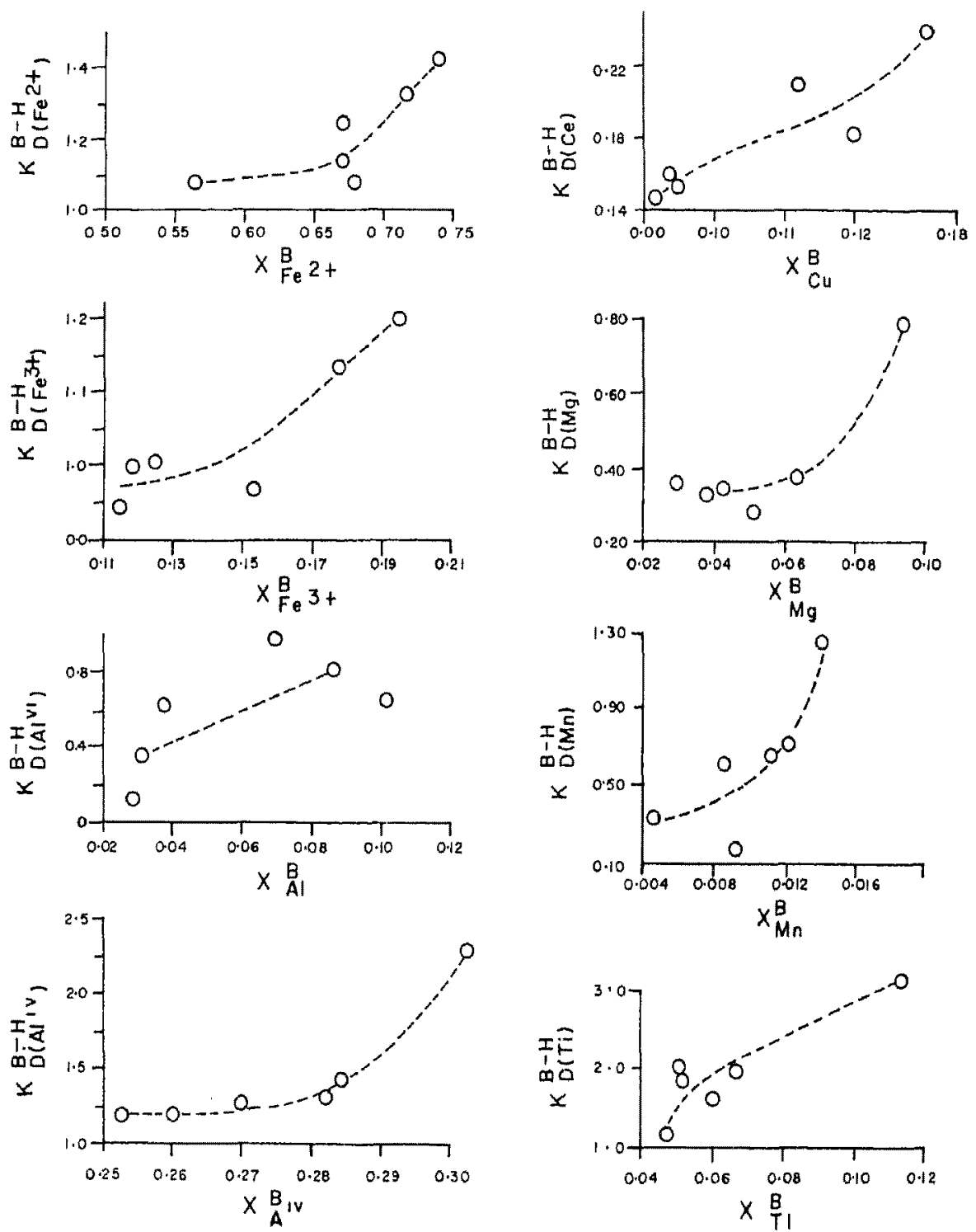

Figure 3. Variations of $K_{D}$ values of major elements between coexisting biotite and hornblende from Ambalavayal. 

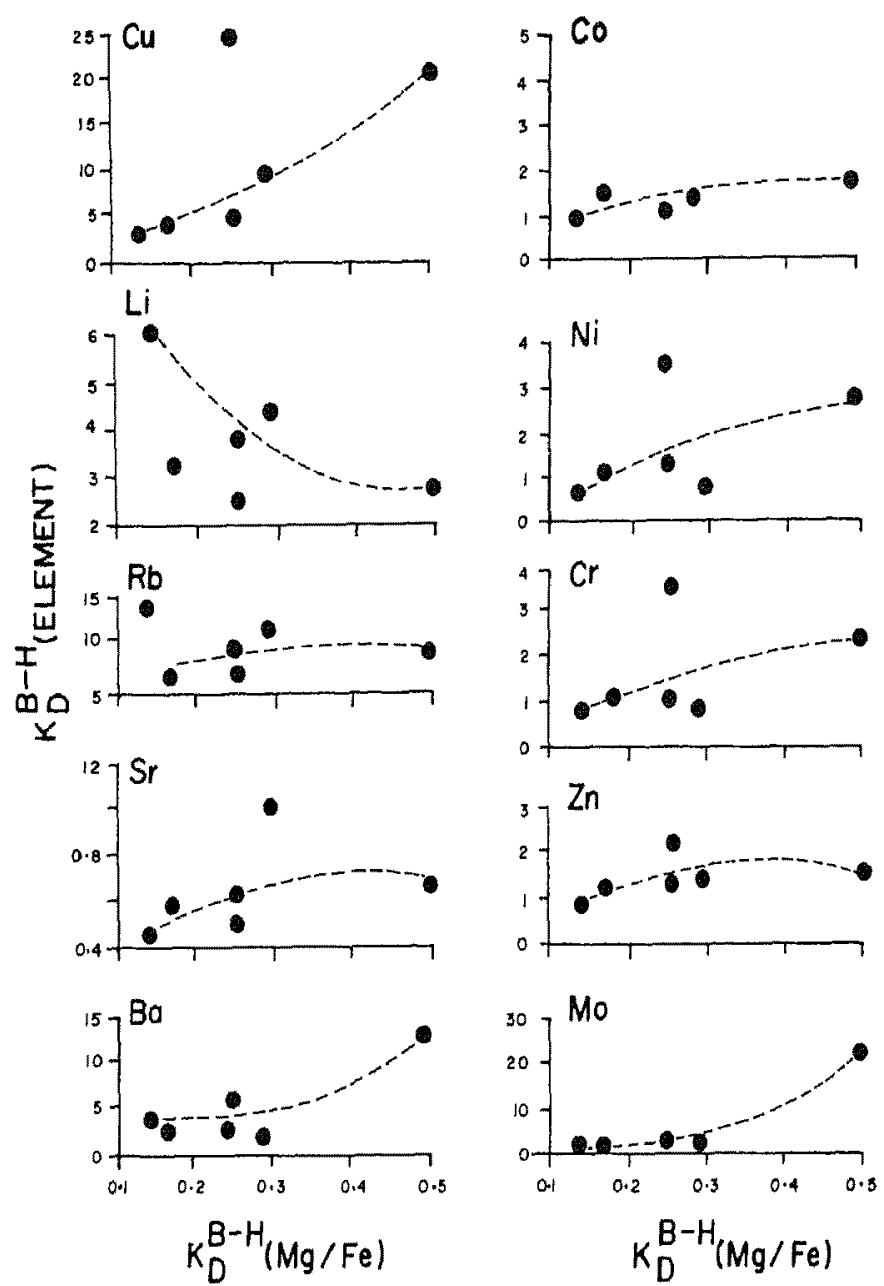

Figure 4. Variations of trace element $K_{0}$ values between coexisting hornblende and biotite from Ambalavayal.

is observed in the distribution of $\mathrm{Ba}, \mathrm{Cu}, \mathrm{Mo}$ and $\mathrm{Co}$, whereas $\mathrm{Sr}, \mathrm{Li}, \mathrm{Zn}, \mathrm{Cr}, \mathrm{Ni}$ and $\mathrm{Rb}$ show an overall correlation, suggesting the maintenance of near-chemical equilibrium during the crystallization of the minerals. The increase in $\mathrm{Li}$ and the decrease in other trace elements like $\mathrm{Cu}, \mathrm{Ni}, \mathrm{Co}, \mathrm{Zn}, \mathrm{Sr}$ and $\mathrm{Cr}$ with decreasing $\mathrm{Mg} / \mathrm{Fe}$ values correspond with the crystal-chemical characters.

\section{Intensive parameters}

As shown by Wones and Eugster (1965), the dominant factors that influence the conditions of crystallization of biotite are temperature and $\mathrm{fO}_{2}$. Calculations based on the composition of biotite will hence give the minimum values of $f \mathrm{O}_{2}$. The most important elements to be considered are $\mathrm{Fe}^{2+}$ and $\mathrm{Mg}$ as the variations of these elements are largely temperature dependent. Also, $\mathrm{Fe}^{3+}$ and $\mathrm{Fe}^{2+}$ give an indication of 
Tabie 5. Trace element analyses of hornblendes and biotites from Ambalavayal.

\begin{tabular}{lrrrrrrrrrrrrrr}
\hline & $\mathrm{Ba}$ & $\mathrm{Bi}$ & $\mathrm{Co}$ & $\mathrm{Cr}$ & $\mathrm{Cu}$ & $\mathrm{Li}$ & $\mathrm{Mo}$ & $\mathrm{Ni}$ & $\mathrm{Pb}$ & $\mathrm{Rb}$ & $\mathrm{Sr}$ & $\mathrm{V}$ & $\mathrm{Zn}$ & $\mathrm{Zr}$ \\
\hline Hornblende & & & & & & & & & & & & & & \\
A/HB/1 & 72 & 50 & 136 & 122 & 2 & 89 & 24 & 86 & 40 & 62 & 54 & 120 & 1272 & 180 \\
$\mathrm{~A} / \mathrm{HB} / 2$ & 64 & 58 & 128 & 128 & 4 & 88 & 22 & 98 & 34 & 56 & 66 & 130 & 1310 & 170 \\
$\mathrm{~A} / \mathrm{HB} / 3$ & 76 & 48 & 132 & 116 & 6 & 92 & 38 & 80 & 48 & 72 & 48 & 110 & 1344 & 280 \\
$\mathrm{~A} / \mathrm{HB} / 4$ & 22 & 74 & 148 & 128 & 4 & 42 & 24 & 104 & 60 & 24 & 27 & 100 & 1210 & 260 \\
$\mathrm{~A} / \mathrm{HB} / 5$ & 30 & 60 & 146 & 116 & 2 & 72 & 2 & 122 & 46 & 50 & 39 & 140 & 1360 & 160 \\
A/HB/6 & 60 & 78 & 153 & 124 & 4 & 48 & 14 & 102 & 38 & 30 & 15 & 100 & 1284 & 460 \\
Mean & 54 & 61 & 141 & 122 & 4 & 72 & 21 & 99 & 44 & 49 & 42 & 117 & 1297 & 252 \\
\hline Biotite & & & & & & & & & & & & & & \\
A/BT/1 & 426 & 170 & 529 & 426 & 50 & 350 & 44 & 310 & 108 & 582 & 33 & 60 & 2600 & 300 \\
A/BT/2 & 176 & 78 & 175 & 152 & 18 & 284 & 16 & 105 & 50 & 315 & 38 & 10 & 1530 & 100 \\
A/BT/3 & 224 & 141 & 144 & 118 & 32 & 216 & 28 & 98 & 84 & 462 & 24 & 52 & 1840 & 220 \\
A/BT/4 & 88 & 64 & 154 & 98 & 14 & 260 & 24 & 84 & 38 & 342 & 12 & 20 & 1142 & 400 \\
A/BT/5 & 418 & 86 & 235 & 268 & 42 & 204 & 46 & 320 & 96 & 468 & 26 & 24 & 1860 & 280 \\
A/BT/6 & 84 & 152 & 220 & 86 & 39 & 212 & 26 & 78 & 34 & 320 & 16 & 58 & 1780 & 360 \\
Mean & 236 & 115 & 243 & 191 & 33 & 254 & 31 & 166 & 68 & 415 & 25 & 37 & 1792 & 277 \\
\hline
\end{tabular}

Table 6. Distribution coefficients of elements between coexisting biotite and hornblende from Ambalavayal.

\begin{tabular}{ccccccccccccccc}
\hline$K_{D}^{B-H}$ & $\mathrm{Mg} / \mathrm{Fe}$ & $\mathrm{Ba}$ & $\mathrm{Bi}$ & $\mathrm{Co}$ & $\mathrm{Cr}$ & $\mathrm{Cu}$ & $\mathrm{Li}$ & $\mathrm{Mo}$ & $\mathrm{Ni}$ & $\mathrm{Pb}$ & $\mathrm{Rb}$ & $\mathrm{Sr}$ & $\mathrm{V}$ & $\mathrm{Zn}$ \\
\hline 1 & 0.25 & 5.9 & 3.4 & 3.9 & 3.5 & 2.5 & 3.9 & 1.8 & 3.6 & 2.7 & 9.4 & 0.6 & 0.5 & 2.1 \\
2 & 0.17 & 2.3 & 1.3 & 1.4 & 1.2 & 4.5 & 3.2 & 0.7 & 1.1 & 1.5 & 3.2 & 0.6 & 0.1 & 1.2 \\
3 & 0.25 & 2.9 & 2.9 & 1.1 & 1.0 & 5.4 & 2.4 & 0.7 & 1.2 & 1.8 & 2.4 & 0.5 & 0.5 & 1.4 \\
4 & 0.14 & 4.0 & 0.9 & 1.0 & 0.8 & 3.5 & 6.2 & 1 & 0.8 & 0.6 & 6.2 & 0.4 & 0.2 & 0.9 \\
5 & 0.50 & 13.9 & 1.4 & 1.6 & 2.3 & 21 & 2.8 & 23 & 2.6 & 2.1 & 2.8 & 0.7 & 0.2 & 1.4 \\
6 & 0.29 & 1.4 & 2.0 & 1.4 & 0.7 & 9.8 & 4.4 & 1.9 & 0.8 & 0.9 & 4.4 & 1.1 & 0.6 & 1.4 \\
Mean & 0.32 & 5.2 & 2.0 & 1.7 & 1.6 & 11.5 & 3.8 & 4.9 & 1.7 & 1.6 & 4.7 & 0.7 & 0.4 & 1.4 \\
\hline
\end{tabular}

the degree of oxidation. Composition of the Ambalavayal biotite when related to Wones and Eugster's (1965) experimental system suggest that oxygen fugacities during biotite crystallization were slightly higher than that defined by the Ni-NiO buffer and that the granite magma was buffered with respect to oxygen by oxides existing within the magma (Dodge et al 1969; Dodge and Ross 1971). If buffering continued during the crystallization of both biotite and hornblende, the tie lines between coexisting biotite and hornblende tend to be parallel to Wones and Eugster's estimated trends of buffered biotites. This is the case with Ambalavayal, where tie lines between coexisting biotites and hornblendes lie almost parallel to the trends of buffered biotite in the compositional triangle, $\mathrm{Fe}^{3+}-\mathrm{Fe}^{2+}-\mathrm{Mg}$ (figure 5). Although ferric iron plays different structural roles in the micas and amphiboles, the parallelism of the biotite-hornblende tie lines with those of the buffered biotites indicate that the effect of oxygen pressure with respect to ferrous-ferric iron distribution is almost the same for biotite and hornblende. This is consistent with the observation that hornblende and biotite of 


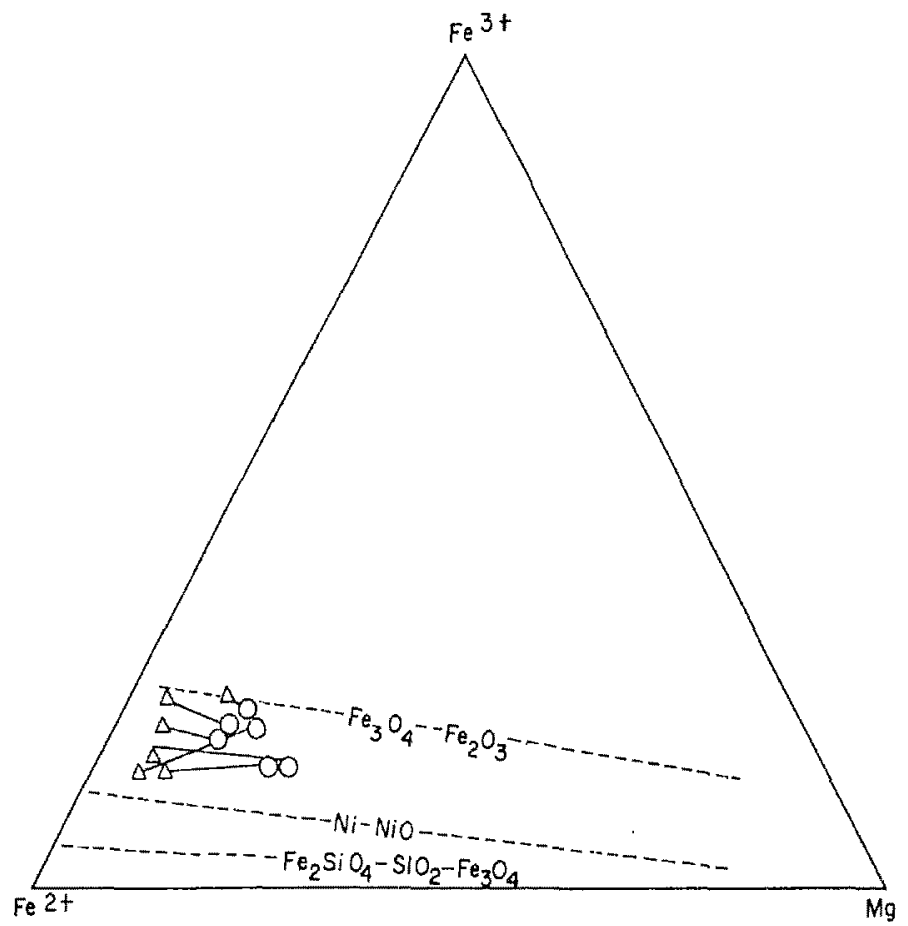

Figure 5. $\mathrm{Fe}^{3+}-\mathrm{Fe}^{2+}-\mathrm{Mg}$ plots of coexisting biotite (circles) and hornblende (triangles) from Ambalavayal. The buffer limits are after Wones and Eugster (1965).

plutonic rocks commonly formed in an environment closed to oxygen with oxygen fugacities determined by buffer reactions (Wones and Eugster 1965).

Qualitative aspects of intensive variables such as $T, P, f \mathrm{H}_{2} \mathrm{O}$ and $f \mathrm{O}_{2}$ can be deduced from the sequence of crystallization of constituent minerals. The sequence of crystallization at $T-\mathrm{fO}_{2}$ constrained to the Ni-NiO buffer for a rock of adamellitic composition was determined by Maaloe and Wyllie (1975). Their data show that hydrous minerals like biotite crystallize early under wet conditions and late under dry conditions. Hornblende and biotite are texturally late crystallized minerals in the Ambalavayal granite. This, together with the presence of pegmatites and aplites in the granite suggest an increase in $f \mathrm{H}_{2} \mathrm{O}$ to a probable saturation towards the final stages of crystallization.

Ishihara (1977) noted that Fe-Ti oxides indicate the relative levels of oxygen fugacity. His 'magnetite-series' refers to granites with high total $\mathrm{Fe}-\mathrm{Ti}$ oxides with higher proportion of magnetite to ilmenite. The high $\mathrm{Fe}^{3+} / \mathrm{Fe}^{2+}$ ratios of coexisting biotites and hornblendes indicate higher oxygen fugacities during their crystallization $\left(\mathrm{fO}_{2}\right.$ $>$ Ni-NiO). An estimate of $\mathrm{fO}_{2}$ is depicted in figure 6 with the aid of an independent geothermometer obtained from coexisting feldspar pairs. Santosh (1986) estimated crystallization temperatures of $704-740^{\circ} \mathrm{C}$ for the coexisting alkali feldspar-plagioclase pairs from Ambalavayal, based on the mole \% Ab content following Brown and Parsons' (1981) method. For granitic plutons, the lower limit of temperature is their wet solidus. As each stability field has pressure contours, the solidus for granitic melts in 


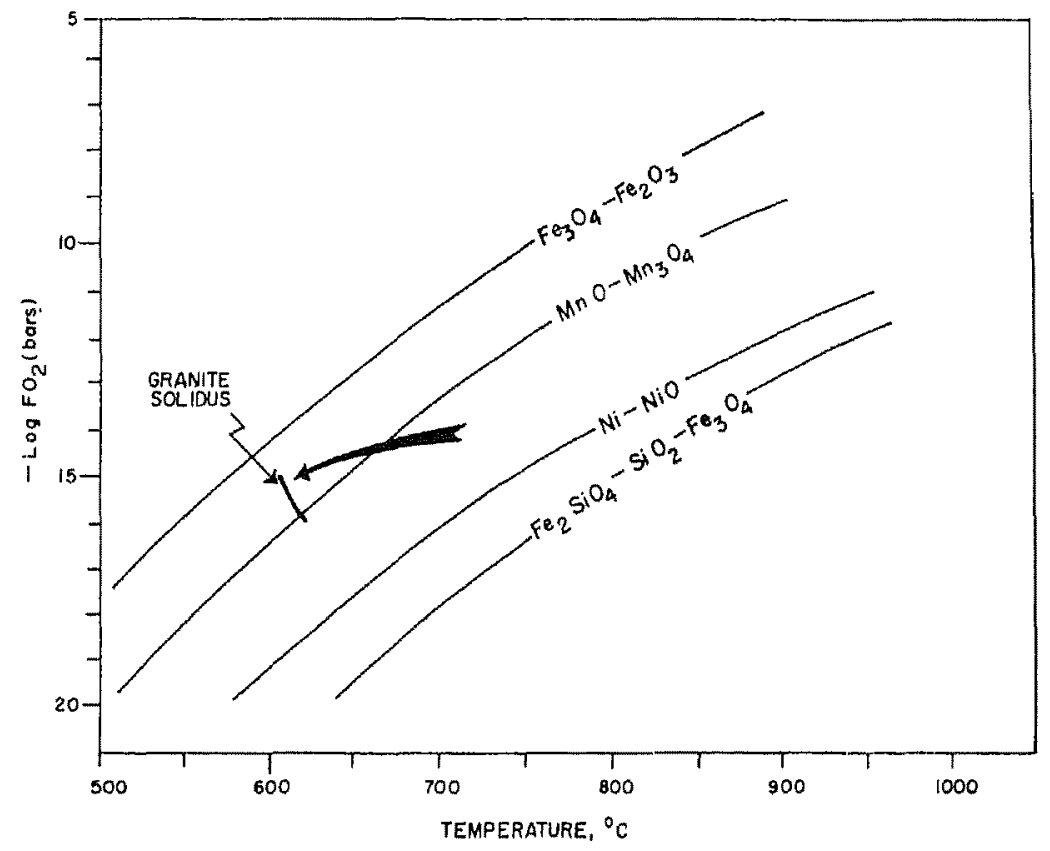

Figure 6. Log $\mathrm{fO}_{2}$ vs temperature diagram with buffer limits, after Wones and Eugster (1965), showing the stability field of biotites from Ambalavayal. The upper limit of solidus temperature has been estimated from independent two-feldspar geothermometer (see text for further discussion).

equilibrium with biotite can be plotted. Thus, the stability fields depicted in figure 6 are derived from the two-feldspar geothermometer, which defines a window in $P-T-f \mathrm{O}_{2}$ space, denoting high $\mathrm{fO}_{2}$ conditions of crystallization of about $10^{-15}$ bars. The result is consistent with the qualitative estimate that the magnetite series granites crystallize at higher levels of $\mathrm{fO}_{2}$, well above the $\mathrm{Ni}-\mathrm{NiO}$ buffer.

\section{Acknowledgements}

I thank the Director, cEss and the late Dr N G K Nair for constant encouragement and support.

\section{References}

Anderson J L 1980 Am. J. Sci. 280289

Brown W L and Parsons I 1981 Contrib. Mineral. Petrol. 5443

Czamanske G K, Wones D R and Richelberger J C 1977 Am. J. Sci. 2771073

Day H W, Brown V M and Abraham K 1980 Bull. Geal. Soc. Am. 911669

Dodge F C W, Smith V C and Mays R E 1969 J. Petrol. 10250

Dodge F C W and Ross D C 1971 J. Geol. 79158

Foster M D 1960 Interpretation of the composition of the trioctahedral micas, us Geol. Surv. Professional Paper, 354-B, pp. 48

Gorbatschev R 1970 Bull. Geol. Surv. Finland 4223 
Ishihara S 1977 Min. Geol. J. 27293

Kretz R 1959 J. Geol. 67371

Kretz R 1960 Geachim. Cosmochim. Acta 20161

Leake B E 1978 Can. Mineral. 16501

Leelanandam C 1970 J. Petrol. 11475

Maaloe S and Wyllie P J 1975 Contrib. Mineral. Petrol. 52175

Nair N GK, Santosh M, Thampi P K and Balasubramonian G 1982 Q. J. Geol, Min. Metall. Soc. India 5428

Santosh M 1986 J. Geol. Soc. India 27185

Santosh M and Nair N G K 1983 Proc. Indian Acad. Sci. (Earth Planet. Sci.) 92297

Santosh M, Nair N G K, Gopalan K and Pande K 1985 J. Geol. Soc. India (in press)

Saxena S K 1966 Neues Jahrb. Mineral Monatsh 167

Stephenson N C N 1977 Lithos 109

Wones D R and Eugster H P 1965 Am. Mineral. 501228 